\title{
Does Agricultural Trade Competitiveness Matter? The Case of the CIS Countries
}

\author{
Tamás Mizik, Péter Gál, Áron Török \\ Corvinus University of Budapest, Hungary
}

\begin{abstract}
The paper aims to analyse the comparative advantage patterns of agriculture in the Commonwealth of Independent States. It is relatively understudied in the literature, especially in Central Asia. Agriculture still plays an important role in the region but in a different way than before. Despite that, the majority of the CIS countries are net food importers. Based on the revealed comparative advantage (RCA) index, country-level analysis shows that Moldova, Kyrgyzstan and Armenia have the highest Balassa indices in the region, and Belarus, Ukraine and Azerbaijan are also having some comparative advantage. Product level analysis pointed out that the region's major agricultural export products groups are cereals. It is important to emphasise that the top five product groups have high, between 3.0-4.4, RCA values. It implies that the regional trade structure is consistent with comparative advantages. However, stability and duration tests show that these are not persistent, since survival chances fell appreciably from 2000-2003 to 2012-2015.
\end{abstract}

\section{Keywords}

CIS, agri-food trade, trade structure, revealed comparative advantages.

Mizik, T., Gál, P. and Török, Á. (2020) "Does Agricultural Trade Competitiveness Matter? The Case of the CIS Countries", AGRIS on-line Papers in Economics and Informatics, Vol. 12, No. 1, pp. 61-72. ISSN 1804-1930. DOI 10.7160/aol.2020.120106.

\section{Introduction}

The Commonwealth of Independent States (CIS) was established after the collapse of the Soviet Union. The transition from centrally planned to market economies has caused and is still causing difficulties. Agricultural production and trade have been among the most important areas affected by policy changes (Lerman et al, 2004; Csaki and Forgacs, 2008). As agriculture in these countries is still an important sector in many ways, such as agricultural value added or employment, the in-depth analysis of the sector is justified by itself. There is a lack of comprehensive analysis of CIS countries agriculture in the related literature (Kožar et al, 2016).

The time horizon of the analysis covers 16 years, from 2000 to 2015 . Right before that, fundamental changes took place and the former Soviet countries faced severe distortions caused by market transition and privatisation (Buchenrieder et al., 2009). From 2000, economic growth has been accelerated, mostly driven by the energy sector, therefore agriculture became relatively less and less important in the Central Asian countries (Mogilevskii and Akramov, 2014). According to Ahrend (2004), it is particularly true for Russia between 1997-2003, where revealed comparative advantage was limited to some raw materials and energy-based products. It is the same for Kazakhstan, where only low value added raw materials showed comparative advantage, and agricultural and food industrial products showed weakening competitive position (Madiyarova et al., 2018). However, this sector still plays an important role in the CIS countries compared to the developed world. For example, in the analysed period, the share of agriculture in the gross domestic product (GDP) decreased from $5.8 \%$ to $5.1 \%$ in Russia or from $14.5 \%$ to $12.1 \%$ in Ukraine, but it was only $1.1 \%$ in the USA and decreased from $2.5 \%$ to $1.4 \%$ in the EU (World Bank WDI, 2019). It is worth mentioning that Russia and Ukraine have been able to restructure their agricultural trade flows to new markets by 2001, while other CIS countries mainly traded amongst themselves (Freinkman et al., 2004). It is important to distinguish between CIS and non-CIS countries as the ideal skills are different in the CIS: such as the importance of personal relationships, Russian fluency or lack 
of need to meet international standards (Gorton and White, 2009).

Several studies using different types of Balassatype indices can be found at country level. One of the OECD's (Organisation for Economic Co-operation and Development) book analysed agricultural comparative advantage at the country level (Liapis, 2011). Among the CIS countries only Kazakhstan and Ukraine had agricultural comparative advantage in 1997 on the aggregated agricultural level. However, this list was even shortened to Ukraine in 2007. Liefert (2002) concluded that Russian agricultural output has comparative disadvantage compared to agricultural input in 1996-1997. He used domestic resource cost (DRC) and social cost-benefit ratio (SCB). Cimpoies (2013) used the Balassa index and found relative trade advantage for Moldova between 2007 and 2011 and 10 positive values out of the 24 agri-food products. The results indicated that Moldova has some advantage in diary, vegetable, tobacco and beverages production. On the other hand, values decreased dramatically for sugar or oilseeds due to old technologies, low quality and inefficiency. Karasova (2016) calculated cluster comparative advantage for different Ukrainian products and cereals and oilseed (mainly sunflower) were found to be highly competitive in 2014. Ishchukova and Smutka (2013) have obtained high and stable Balassa values for Russia in cereals (around 4), oilseeds (almost 3) and tobacco (around 2) sector between 1998 and 2010. It is worth mentioning that regional values showed huge differences, far lower RCA values for the same product in the European Union (EU) than in CIS. One reason is geographical location, because transport cost per unit is higher for these bulk products. In terms of primary and processed products, the former ones resulted in slightly higher values (e.g., 1.2 compared to 0.9 in 2010). These results are in line with Zhemoyda and Gerasymenko (2009). They also obtained higher Russian and Ukrainian revealed comparative advantages for raw materials between 2000 and 2004. Benesova et al. used RCA, RC (revealed competitiveness) and Lafay index to analyse the Russian agricultural trade between 2000 and 2014 (Benesova et al., 2017). Raw materials, especially cereals due to the great soil abundance, showed higher RCA values as well as promising future opportunities. Ainur and Diana found decreasing Kazakh agri-food performance based on Lafay index between 2001 and 2012 (Amirbekova and Madiyarova, 2015). Khabiti (2008) obtained the same results by using RCA for 1999-2006. Mostly energy and some manufactured goods were competitive. The trade structure of the country was in line with these results, since these products were exported while uncompetitive agricultural goods were imported.

Wijnands et al. (2015) carried out a comprehensive study on the competitiveness of CIS and EU agri-food chains and found low competitiveness in almost all CIS food sectors by using EU's major food producers as a benchmark. Based on relative net trade advantage (RTA), the analysed CIS countries showed high values for raw materials, especially for pork and poultry (Russia, Kazakhstan), cereals and oilseeds (Ukraine), potatoes (Ukraine and Belarus) and tomatoes (Belarus in 2013. Regarding processed products, again Ukraine performed the best (strong values for processed products out of cereals, oilseeds) followed by Belarus (above-average values for pork, potatoes and tomatoes based processed products). The overall conclusion of the study was that the major factor behind the competitiveness of CIS agri-food sector was low prices due to cheap resource endowments. It was strengthened by Maryam at al. (2018) results, where natural resource-based Russian products had a comparative advantage. Maslova et al. (2019) used an integrated indicator, including export price and export share to measure the trade performance of the Eurasian Economic Union (Armenia, Belarus, Kazakhstan, Kyrgyzstan, and Russia). According to their result, the Kazakh and Russian grain production proved to be competitive due to the low domestic prices and production growth.

As a conclusion to the introduction, the major characteristics of the literature review are summarised in Table 1.

The paper focuses on the international trade patterns of the CIS countries in 2000-2015. The analysed economies are Armenia, Azerbaijan, Belarus, Kazakhstan, Kirgizstan, Moldova, Russia and Ukraine ${ }^{1}$, while Uzbekistan, Tajikistan and Turkmenistan are excluded due to lack of appropriate data. The paper is structured as follows. First, the description of methods and data used is presented, followed by the main characteristics of CIS agriculture and trade. The third part of the paper analyses the comparative advantages of CIS agricultural trade together with their stability and duration. The final part concludes.

${ }^{1}$ It should be noted that Ukraine has never had full CIS membership. 


\begin{tabular}{|l|c|c|c|l|}
\hline Author & Time horizon & Analysed country & Research tool & \multicolumn{1}{|c|}{ Comparative advantage } \\
\hline Ahrend (2006) & $1997-2003$ & Russia & RCA & $\begin{array}{l}\text { Yes, for raw materials and energy- } \\
\text { based products }\end{array}$ \\
\hline Ainur and Diana (2015) & $2001-2012$ & Kazakhstan & Lafay index & Yes, for some sectors, but decreasing \\
\hline Benesova et al. (2017) & $2000-2014$ & Russia & $\begin{array}{c}\text { RCA, RC and } \\
\text { Lafay index }\end{array}$ & $\begin{array}{l}\text { Yes, for raw materials, especially } \\
\text { cereals }\end{array}$ \\
\hline Cimpoies (2013) & $2007-2011$ & Moldova & RCA & Yes, 10 out of 24 agri-food products \\
\hline $\begin{array}{l}\text { Ishchukova and Smutka } \\
\text { (2013) }\end{array}$ & $1998-2010$ & CIS & RCA & $\begin{array}{l}\text { Yes, for bulk products and higher for } \\
\text { raw materials }\end{array}$ \\
\hline Karasova (2016) & 2014 & Ukraine & $\begin{array}{c}\text { Cluster comparative } \\
\text { advantage }\end{array}$ & Yes, especially for cereals and oilseeds \\
\hline Khabiti (2008) & $1999-2006$ & Kazakhstan & RCA & $\begin{array}{l}\text { Yes, mainly for energy and } \\
\text { manufactured goods, but decrasing }\end{array}$ \\
\hline Liefert (2002) & $1996-1997$ & Russia & DRC, SCB & Yes, for the input not the output \\
\hline Liapis (2011) & 1997 and 2007 & OECD & RCA & Yes, but only for Ukraine \\
\hline Madiyarova et al., 2018 & $2001-2016$ & Kazakhstan & RCA & Yes, only for raw materials \\
\hline Maryam at al. (2018) & 2015 & BRICS & RCA & $\begin{array}{l}\text { Yes, for natural resource-based Russian } \\
\text { products }\end{array}$ \\
\hline Maslova et al. (2019) & $2012-2016$ & EAEU & Integrated indicator & Yes, for Kazakh and Russian grain \\
\hline Wijnands et al. (2015) & 2013 & CIS & $\begin{array}{l}\text { Yes, but mostly for raw materials and } \\
\text { for only Ukrainian processed products }\end{array}$ \\
\hline $\begin{array}{l}\text { Zhemoyda and Gerasymenko } \\
\text { (2009) }\end{array}$ & $2000-2004$ & Russia and Ukraine & RCA & Yes, for raw materials \\
\hline Soure:A & & & \\
\hline
\end{tabular}

Source: Authors' elaboration

Table 1: Summary of the studies on the regional agricultural comparative advantage.

\section{Materials and methods}

The paper employs the seminal work of Balassa (1965). Balassa's measurement of revealed comparative trade advantage is based on the concept of Ricardian trade theory. The original index of revealed comparative advantage defined as follows (Balassa, 1965): $\mathrm{B}_{\mathrm{ij}}=\mathrm{RCA}_{\mathrm{ij}}=\left(\frac{X_{i j}}{X_{i t}}\right) /\left(\frac{X_{n j}}{X_{n t}}\right)$,

where $X$ means exports, $i$ indicates a given country, $j$ is a given product, $t$ is a group of products and $n$ is a group of countries. It follows that revealed comparative advantage (or disadvantage) can be calculated by comparing a given country's export share of its total exports with the export share in total exports of a reference group of countries. Normally "world" is the reference group. If the B index is higher than 1, the given country has a comparative advantage compared to the reference countries or, in contrast, a revealed comparative disadvantage if $\mathrm{B}$ is less than 1 . RCA is an outstanding tool of descriptive trade statistics and can help to avoid misinterpretation of sectoral or country-level results (Deardorff, 2011).

The Balassa-index is criticised because it usually neglects the different effects of agricultural policies and exhibits asymmetric values. Trade structure is distorted by different state interventions and trade limitations. That is the reason why RCA calculation is based on exports data where this impact is smaller compared to the imports (Bojnec, 2001). The relatively long time series also helps to lower this possible distortion. Moreover, due to the asymmetric value of the $\mathrm{B}$ index, it extends from 1 to infinity if a country enjoys a comparative advantage, but in the case of comparative disadvantage, it varies between 0 and 1 , which overestimates a sector's relative weight. Therefore, there are many other specifications of the RCA index available, but they are highly correlated (Jámbor and Babu, 2016). All in all, it can be a useful analytical tool in the detection of comparative advantages and predicting its dynamics in a changing environment, such as market changes (Hoang and Tran, 2019).

The stability and durability of the RCA index are also checked in two steps. First, Markov transition probability matrices are calculated and then summarized by using the mobility index, evaluating the mobility across countries and time. Second, following Bojnec and Fertő (2008), a survival function $\mathrm{S}(\mathrm{t})$ is estimated by using the non-parametric Kaplan-Meier product limit estimator, which pertains to the product level distribution analysis of the RSCA index. Following 
Bojnec and Fertő (2008), a sample contains $n$ independent observations $\left(t_{i} ; c_{i}\right)$, where $i=1 \rightarrow n$, and $t_{i}$ is the survival time, $c_{i}$ is the censoring indicator variable with a value of 1 if a failure occurred, e.g., there is no longer a comparative advantage, and 0 otherwise. It is assumed that there are fewer failures than the number of data $(m<n)$. Then, we denote the rank-ordered survival times as $t(1)<t(2)<\ldots<t(m)$. Let $n_{j}$ indicate the risk of failure and let $d_{j}$ denote the number of observed failures at $t_{j}$ time. The Kaplan-Meier estimator of the survival function is then (with the convention that $\hat{S}(t)=1$ if $t<t(1))$ :

$$
\hat{S}(t)=\prod_{t(i)<t} \frac{n_{j}-d_{j}}{n_{j}} .
$$

First, we estimate a single survival function by pooling across all products and years and then we also present results by country. Survival of export relationships is also a precondition for trade deepening and export growth, as suggested by Besedes and Prusa (2011), who also give an excellent review on the mathematical specifications of the survival tests. An even more detailed description of survival tests can be found in the book of Cleves et al. (2004) who also use Stata as the authors of this article to make the necessary calculations. As evident from their works, survival tests have a number of assumptions such as the lack of independence or censored values. Moreover, these works also well describe the way Wilcoxon and log-rank tests are run and specified.

The paper employs CIS agricultural trade data of the World Bank World Integrated Trade Solution (WITS) database at HS-6 level between 2000 and 2015 on agricultural products (chapters 1-24, see Annex 1. in the Appendix for the name of the product categories) ending up in 38,770 observations. The paper concentrates on the export side of the revealed comparative advantage index (B or RCA index) to exclude imports, which is more likely to be influenced by agricultural policy interventions.

\section{Results and discussion}

\section{CIS agriculture and trade}

The fundamental production factor of the sector is agricultural land. Its highest share can be found in Kazakhstan (80\%), Moldova (75\%) and Ukraine $(72 \%)$, out of which arable land is dominant in Ukraine $(79 \%)$, Moldova $(74 \%)$ and Belarus $(66 \%)$ based on FAO (2019). In order to measure the relevance of agriculture, three indicators were used: value added as a share of GDP (\%), the share of agricultural employment (\%) and the size of agricultural production (million international dollar ${ }^{2}$ ). The following diagram summarises these indicators (Figure 1).

It is evident from the Figure 1 that agriculture

\begin{abstract}
${ }^{2}$ International dollar is a theoretical currency used by FAO, World Bank, IMF or UN. It combines the exchange rate, purchasing power parity and international average prices of commodities. It shows the purchasing power that the US dollar had in the United States in the given year. Therefore, it is better for comparisons, but cannot be directly converted to other currencies simply by using exchange rates.
\end{abstract}

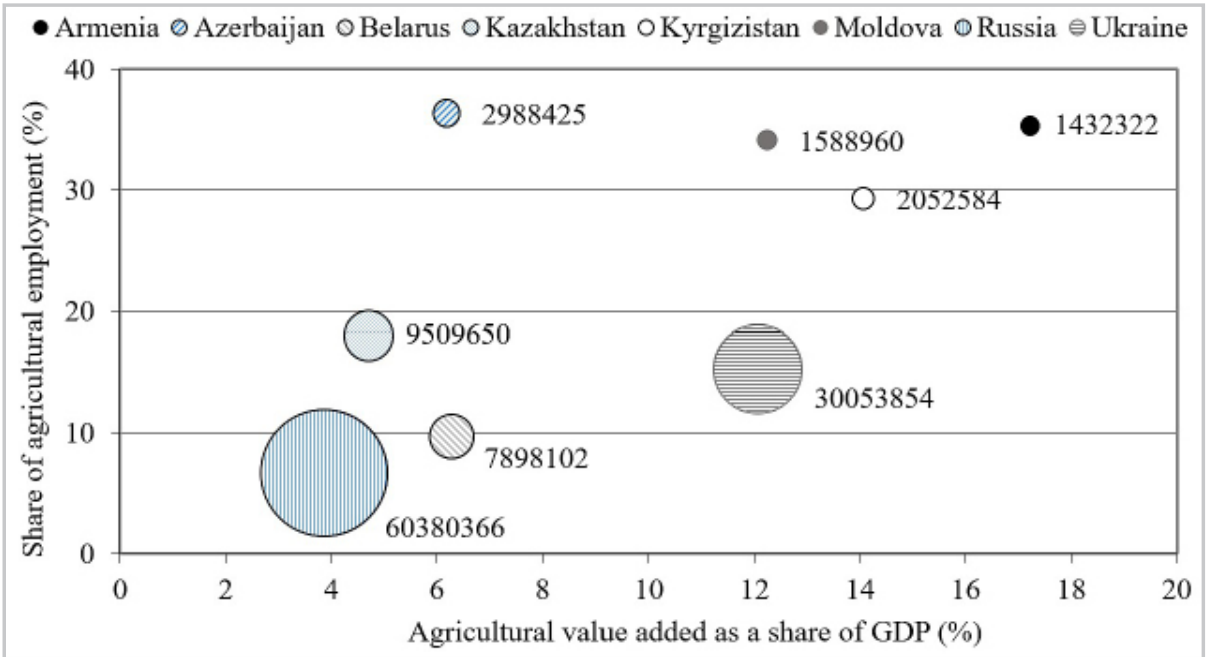

Note: The size of the circles reflects to the size of agricultural production measured in thousand international dollars. The middle of the circle shows $\mathrm{x}$ (agricultural value added as a share of GDP) and y (share of agricultural employment) values.

Source: Authors' composition based on World Bank WDI (2019) database and FAO (2019) database

Figure 1: Agricultural value added, agricultural employment and size of agricultural production in the CIS, 2015 
plays an important role in the CIS region. This is especially true for Armenia where it is reflected in the high share of agricultural value added in GDP as well as the high share of employment (17.2\% and $35.3 \%$ respectively). At the other end, Russian agriculture represents only $3.8 \%$ of GDP and $7.0 \%$ of employment. The case of Azerbaijan should also be highlighted here, where agriculture is a significant employer with $36.4 \%$ share, though it contributes to the national GDP only by $6.2 \%$, implying serious labour efficiency problems. The share of agricultural employment was only $4.5 \%$ and $1.7 \%$ in the EU and USA respectively, while agricultural value added was even lower, only $1.4 \%$ (EU) and $1.1 \%$ (USA) in the same year (World Bank WDI, 2019). Generally, these indicators show decreasing trend, especially in the developed countries.

Regarding the size of agricultural production, figure 1 suggests that Russia and Ukraine have the largest production potentials, followed by Kazakhstan and Belarus. The sum of the remaining four countries' production is more or less equal to the Belarussian production.

The role of agriculture can also be measured by its share in total exports. It is evident from Table 2 that agriculture gives the most significant share in total exports in Moldova (44\% in 2012-2015), followed by Ukraine (32\%) and Armenia (26\%). In other words, almost half, a third and a quarter of export revenue came from agriculture in these countries, respectively. Besides, it shows an increasing trend in Armenia due to the remarkable expansion of agricultural exports to total exports in the last four years, as well as in Ukraine, where the total exports declined by $30 \%$ from 2014 to 2015 , while agricultural exports decreased only by $13 \%$ (World Bank Wits, 2019). In the case of Ukraine, this process was accelerated by the signed DCFTA $^{3}$ resulting

${ }^{3}$ Deep and Comprehensive Free Trade Agreement. in even lower EU trade barriers and increased investment supports after the global crisis (Borodina and Krupin, 2018). On the other hand, agricultural exports gave less than $7 \%$ of total exports in 2012-2015 in Russia, Kazakhstan and Azerbaijan. In the case of Russia, the embargo increased the agricultural performance due to the higher, strategic self-sufficiency, preferential agricultural credits and higher producer prices (Kalinina, 2017). This process was further strengthened by the governmental import substitution policy that came into force in 2010 and targeted high self-sufficiency rates like $95 \%$ for cereals, $90 \%$ for milk and dairy products or $85 \%$ for meat and meat products planned to be reached by 2020 (RPA, 2009). In light of these significant impacts, it seems to be very hard for exporters to regain the Russian agri-food markets in the future if at all. However, it should be kept mind in that only a small share of agricultural products are traded, e.g. 16.5\% for the cereals (FAO, 2019), which is the major product of the region, meaning that most of the countries feed themselves.

As to CIS agricultural exports, continuous growth can be seen in every country, though to a different extent (Table 3). On the one hand, countries like Azerbaijan and Ukraine increased their agricultural exports more than seven times from 2000-2003 to 2012-2015, while on the other hand, respective growth in Moldova was "only" 2,5 times. However, it should be clearly seen that the magnitude of the Russian and Ukrainian agricultural export is much larger than any other countries in the region.

Analysing the agricultural trade balance gives further insights into the patterns described above (Table 4). First, the CIS region has traditionally been a net importer of agricultural goods. However, due to the notable expansion of Ukrainian exports as well as the huge decline in the Russian agricultural imports, the region achieved a surplus in 2014 and 2015 (1.1 and 9.4 billion USD, respectively).

\begin{tabular}{|l|r|r|r|r|}
\hline Country & $2000-2003$ & $2004-2007$ & $2008-2011$ & $2012-2015$ \\
\hline Armenia & 14.10 & 14.20 & 18.13 & 25.61 \\
\hline Azerbaijan & 4.83 & 3.90 & 2.20 & 3.44 \\
\hline Belarus & 11.25 & 10.18 & 11.42 & 15.26 \\
\hline Kazakhstan & 7.08 & 4.10 & 3.53 & 3.99 \\
\hline Kyrgyzstan & 10.87 & 17.45 & 12.21 & 12.55 \\
\hline Moldova & 63.84 & 50.02 & 43.95 & 44.26 \\
\hline Russia & 7.61 & 6.15 & 5.71 & 6.52 \\
\hline Ukraine & 12.89 & 13.26 & 20.47 & 31.81 \\
\hline
\end{tabular}

Source: Authors' composition based on WTO (2019) database

Table 2: Share of agricultural exports in total merchandise exports, 2000-2015 (percent). 


\begin{tabular}{|l|c|c|c|c|}
\hline Country & $2000-2003$ & $2004-2007$ & $2008-2011$ & $2012-2015$ \\
\hline Armenia & 63 & 138 & 185 & 378 \\
\hline Azerbaijan & 107 & 368 & 608 & 841 \\
\hline Belarus & 925 & 1842 & 3342 & 5419 \\
\hline Kazakhstan & 709 & 1373 & 2216 & 2823 \\
\hline Kyrgyzstan & 57 & 153 & 222 & 236 \\
\hline Moldova & 395 & 550 & 723 & 983 \\
\hline Russia & 8572 & 16717 & 23845 & 30131 \\
\hline Ukraine & 2340 & 5151 & 11302 & 17255 \\
\hline
\end{tabular}

Source: Authors' composition based on WTO (2019) database

Table 3: Agricultural exports of the CIS, 2000-2015, million USD at current prices.

\begin{tabular}{|l|c|c|c|c|}
\hline Country & $2000-2003$ & $2004-2007$ & $2008-2011$ & $2012-2015$ \\
\hline Armenia & -152 & -239 & -551 & -442 \\
\hline Azerbaijan & -163 & -254 & -670 & -772 \\
\hline Belarus & -294 & -249 & 75 & 825 \\
\hline Kazakhstan & 106 & -324 & -882 & -1366 \\
\hline Kyrgyzstan & 9 & -97 & -394 & -588 \\
\hline Moldova & 225 & 175 & 76 & 228 \\
\hline Russia & -1135 & -2822 & -11927 & -8744 \\
\hline Ukraine & 796 & 1781 & 4942 & 10515 \\
\hline Total & -607 & -2031 & -9332 & -345 \\
\hline
\end{tabular}

Source: Authors' composition based on WTO (2019) database

Table 4: Agricultural trade balance of the CIS, 2000-2015, million USD at current prices.

\begin{tabular}{|l|c|c|c|c|}
\hline Product group & $2000-2003$ & $2004-2007$ & $2008-2011$ & $2012-2015$ \\
\hline Cereals & 26.50 & 26.85 & 29.46 & 31.80 \\
\hline Animal or vegetable fats and oils & 7.74 & 8.46 & 13.71 & 14.62 \\
\hline Dairy products & 8.46 & 10.19 & 8.29 & 6.90 \\
\hline Fish & 7.48 & 4.11 & 6.80 & 6.84 \\
\hline Oil seeds & 5.47 & 3.25 & 5.78 & 5.81 \\
\hline Total & 55.66 & 55.07 & 64.04 & 65.96 \\
\hline
\end{tabular}

Source: Authors' composition based on World Bank WITS (2019) database

Table 5: Export share of the top five agricultural product groups in CIS exports, 2000-2015 (percent).

The latter impact was even higher as the Russian trade deficit declined from 15.0 billion USD (2010) to 363 million USD (2015). Second, in the period analysed, the agricultural trade deficit of the CIS countries has increased with four exceptions: Kazakhstan and Kyrgyzstan turned to be net importers from net exporters, while Belarus became a net exporter. Third, Moldova was able to keep its net exporter position with no significant changes over the analysed period. Finally, only Ukraine, Belarus and Moldova had an agricultural trade surplus in 2012-2015. These processes are part of the international specialisation, where countries try to concentrate on the production of goods in which they have absolute advantage (e.g., land abundant) or relative advantages compared to the other sectors of the economy.
As to agricultural exports by product, cereals were the most important agricultural commodities of the region, providing one-third of its exports (Table 5). Cereals were followed by animal or vegetable fats and oils, dairy products, fish and oilseeds in the period analysed. These product groups gave almost two-thirds of the value of agricultural exports of the region in 2012-2015, suggesting a high and increasing concentration of exports.

In the case of cereals, it should also be kept in mind that the average cereals yield in the region is much lower than in the major producers or trade partners. E.g. it was $5.5 \mathrm{t} / \mathrm{ha}$ in the EU, $5.9 \mathrm{t} / \mathrm{ha}$ in China or 7.4 in the USA, while among the CIS it varied between $1.3 \mathrm{t} / \mathrm{ha}$ (Kazakhstan) and $4.1 \mathrm{t} / \mathrm{ha}$ (Ukraine) in 2015 (FAO, 2019). 


\section{Revealed comparative advantages of CIS agriculture}

The performance of CIS agriculture in international trade can be measured by calculating the Balassa indices described above. Moldova, Kyrgyzstan and Armenia had the highest Balassa indices in most of the years analysed, while Belarus, Ukraine and Azerbaijan enjoyed some comparative advantage at the same time (Table 6). However, Russia and Kazakhstan had a revealed comparative disadvantage in all periods except for 2000-2003. Note that RCA values has been diminishing from 2000-2003 to 2012-2015 in the vast majority of the cases and especially in Moldova and Azerbaijan. These results are generally in line with previous findings as described in the introduction section.

When analysing comparative advantages by products, further specialisation patterns became available (Table 7). It is apparent that all of the most important product groups identified in Table 5 had a comparative advantage in all periods analysed, though to a different extent. On the one hand, the very high comparative advantages of animal or vegetable fats and oils, as well as oilseeds, seem to have diminished significantly, while that of cereals declined only modestly. On the other hand, the comparative advantages of dairy and fish products have somewhat increased from 2000-2003 to $2012-2015$.
Unstable competitive patterns were already justified by the results above. In order to further test its stability, the Markov transition probability matrices were used. It indicates relatively low mobility of the Balassa index for Kazakhstan, Azerbaijan, Russia and Armenia, implying stable patterns of comparative (dis)advantages. Besides these countries, more than $70 \%$ of product groups with a comparative advantage remained persistent for Kyrgyzstan, Moldova and Belarus, while the lowest mobility measures pertained to Ukraine, implying highly changing competitive potentials (Figure 2).

The duration tests also verified the changing structure of agricultural trade-based competitiveness. As it was described in the methodology section, the Kaplan-Meier estimator of the survival function was run on our panel dataset and the results confirm that in general, the survival times are not persistent over the period analysed (Table 8). Survival chances of $94-98 \%$ at the beginning of the period fell to $1-11 \%$ by the end of the period, suggesting that fierce competition exists in CIS agricultural trade.

The highest survival times exist for Moldova, while the lowest are for Russia, but results vary from country to country. However, there is no clear pattern observable between the change in survival times and the rank in CIS agricultural exports. The equality of the survival functions

\begin{tabular}{|l|r|r|r|r|}
\hline Country & $2000-2003$ & $2004-2007$ & $2008-2011$ & $2012-2015$ \\
\hline Armenia & 8.80 & 4.96 & 7.47 & 9.15 \\
\hline Azerbaijan & 11.59 & 6.75 & 1.08 & 1.69 \\
\hline Belarus & 1.71 & 2.27 & 2.34 & 2.17 \\
\hline Kazakhstan & 1.05 & 0.75 & 0.74 & 0.76 \\
\hline Kyrgyzstan & 9.35 & 9.46 & 6.86 & 9.31 \\
\hline Moldova & 33.79 & 29.54 & 22.22 & 18.50 \\
\hline Russia & 0.29 & 0.25 & 0.27 & 0.36 \\
\hline Ukraine & 2.95 & 3.05 & 1.98 & 2.01 \\
\hline
\end{tabular}

Source: Authors' composition based on World Bank WITS (2019) data

Table 6: Balassa indices for CIS countries agricultural exports by country, 2000-2015.

\begin{tabular}{|l|c|c|c|c|}
\hline Product group & $2000-2003$ & $2004-2007$ & $2008-2011$ & $2012-2015$ \\
\hline Cereals & 26.50 & 26.85 & 29.46 & 31.80 \\
\hline Animal or vegetable fats and oils & 7.74 & 8.46 & 13.71 & 14.62 \\
\hline Dairy products & 8.46 & 10.19 & 8.29 & 6.90 \\
\hline Fish & 7.48 & 4.11 & 6.80 & 6.84 \\
\hline Oil seeds & 5.47 & 3.25 & 5.78 & 5.81 \\
\hline
\end{tabular}

Source: Authors' composition based on World Bank WITS (2019) database

Table 7. Balassa indices for CIS countries agricultural exports by the most important product groups, 2000-2015. 


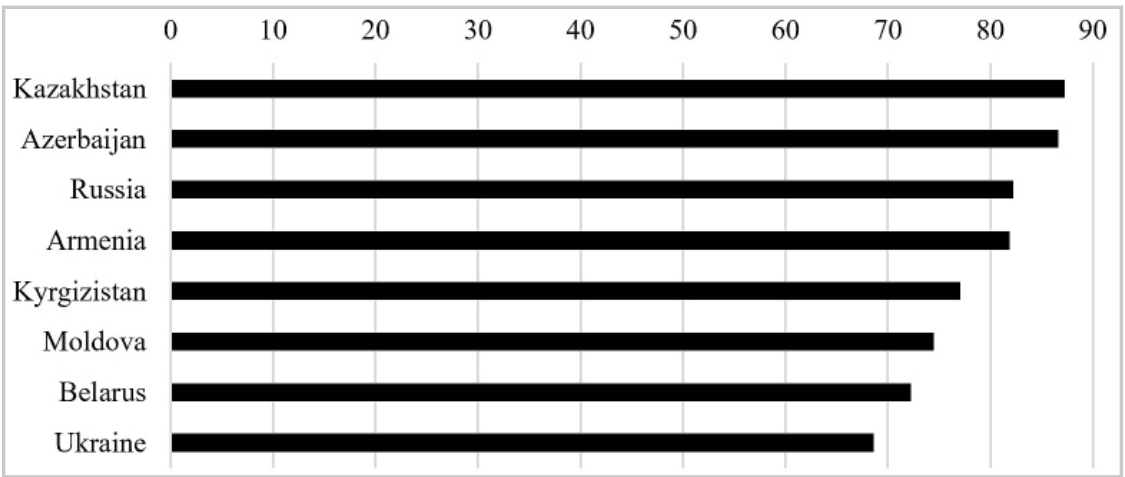

Source: Authors' composition based on World Bank WITS (2019)

Figure 2: The mobility of Balassa indices, 2000-2015, by country, $\%$.

\begin{tabular}{|c|c|c|c|c|c|c|c|c|c|}
\hline Years & Survivor function & Armenia & Azerbaijan & Belarus & Kazakhstan & Kyrgyzstan & Moldova & Russia & Ukraine \\
\hline 2000 & 0.95 & 0.98 & 0.96 & 0.95 & 0.95 & 0.95 & 0.97 & 0.94 & 0.96 \\
\hline 2001 & 0.90 & 0.96 & 0.92 & 0.90 & 0.89 & 0.90 & 0.95 & 0.88 & 0.91 \\
\hline 2002 & 0.86 & 0.93 & 0.89 & 0.85 & 0.84 & 0.85 & 0.92 & 0.82 & 0.87 \\
\hline 2003 & 0.81 & 0.90 & 0.85 & 0.80 & 0.79 & 0.81 & 0.89 & 0.76 & 0.82 \\
\hline 2004 & 0.76 & 0.85 & 0.80 & 0.74 & 0.74 & 0.76 & 0.86 & 0.70 & 0.77 \\
\hline 2005 & 0.71 & 0.83 & 0.75 & 0.69 & 0.68 & 0.72 & 0.82 & 0.64 & 0.72 \\
\hline 2006 & 0.66 & 0.77 & 0.70 & 0.64 & 0.62 & 0.68 & 0.78 & 0.59 & 0.67 \\
\hline 2007 & 0.61 & 0.72 & 0.64 & 0.60 & 0.56 & 0.63 & 0.74 & 0.53 & 0.62 \\
\hline 2008 & 0.55 & 0.66 & 0.57 & 0.55 & 0.50 & 0.58 & 0.71 & 0.47 & 0.56 \\
\hline 2009 & 0.49 & 0.60 & 0.51 & 0.50 & 0.44 & 0.52 & 0.65 & 0.41 & 0.50 \\
\hline 2010 & 0.44 & 0.54 & 0.43 & 0.45 & 0.39 & 0.45 & 0.60 & 0.36 & 0.44 \\
\hline 2011 & 0.37 & 0.47 & 0.37 & 0.38 & 0.33 & 0.38 & 0.54 & 0.30 & 0.37 \\
\hline 2012 & 0.30 & 0.41 & 0.30 & 0.30 & 0.25 & 0.30 & 0.48 & 0.23 & 0.29 \\
\hline 2013 & 0.22 & 0.33 & 0.22 & 0.23 & 0.17 & 0.20 & 0.39 & 0.16 & 0.22 \\
\hline 2014 & 0.13 & 0.23 & 0.13 & 0.14 & 0.08 & 0.10 & 0.28 & 0.09 & 0.13 \\
\hline 2015 & 0.03 & 0.08 & 0.02 & 0.04 & 0.01 & 0.06 & 0.11 & 0.01 & 0.03 \\
\hline
\end{tabular}

Source: Authors' composition based on World Bank WITS (2019)

Table 8: Kaplan-Meier survival rates for Balassa indices and tests for equality of survival functions in CIS agricultural trade, $2000-2015$.

across regional countries can be checked by using two non-parametric tests (Wilcoxon and log-rank tests). Results of the tests show that the hypothesis of equality across survivor functions can be rejected at the $1 \%$ level of significance, meaning that similarities in the duration of comparative advantage across most important regional agricultural exporters are absent (Table 8).

From a trade policy perspective, it is important to know and to interpret correctly these results. Political and economic regionalisation is creating new trade patterns, acting towards harmonization of member states' trade policies. The Eurasian Customs Union and preferential trade agreements with the EU play a key role in realizing comparative advantages on the agri-food markets. Most of the CIS countries are relying heavily on Russia in their agricultural trade, while some of them were able to diversify their export markets (Kožar et al., 2016). In either case, identifying the changing nature of competitive potentials is key to future success.

\section{Conclusion}

The analysis of the CIS region with different versions of Balassa indices is topical and can be found in many studies. One of their common points is that revealed comparative advantages are limited to mostly raw materials due to the resource endowments, especially in Kazakhstan and Russia. On the country level, high RCA values can be noticed for Belarus, Moldova and Ukraine.

According to the basic indicators (value added, employment or contribution to the total exports), agriculture still plays an important role in the region, especially in Armenia, Kyrgyzstan and Moldova. As to the share of the sector in total exports, 
Moldova, Ukraine and Armenia led the way with almost half, third and quarter of every foreign exchange earned via export was coming from agriculture in these countries, respectively. Most of the analysed CIS countries are net importers of agricultural goods, but Belarus became net exporter while Moldova was able to maintain its export surplus during the analysed period. Ukraine is showing continuous and significant growth in agricultural exports, which, strengthened by the huge decline in Russian agricultural imports, transformed the CIS region from a net importer, into a net exporter of agricultural goods. The major agricultural export commodity of the region is undoubtedly cereals, providing almost a third of total agricultural exports. Taking into consideration the relatively low regional yields, it indicates a great potential for further growth in cereals production.

Regarding country-level revealed comparative advantages, Moldova, Kyrgyzstan and Armenia had the highest Balassa indices in the majority of the years analysed for agricultural trade. Belarus, Ukraine and Azerbaijan had some comparative advantage at the same time. These values reflect on the importance of agriculture in the economies of these countries, which is proportionally related to the size of natural resources, like in case of Azerbaijan or Kazakhstan. All of the most important product groups had RCA values above 1 in all periods analysed, implying that the export of agricultural products of the CIS countries corresponds with their revealed comparative advantages. Cereals, animal or vegetable fats and oils, and oilseeds had decreasing values, while dairy products and especially fish were facing increasing revealed comparative advantages. However, it has not turned out to be persistent according to stability and duration tests run on our panel dataset, implying highly changing competitive potentials and fierce regional competition on the agri-food markets. These results are in line with the existing literature, as mostly raw materials have a comparative advantage which generally shows a decreasing trend. Further research might be carried out to analyse and understand the possible reasons behind the results presented above, as well as to compare CIS to other neighbouring countries in this regard. On the agricultural policy level, using revealed comparative advantages can help to better understand the country's export specialisation and international trade performance, which can be the key to future success.

\section{Acknowledgements}

This work was supported by the National Research, Development and Innovation Office under grant number 119669, titled "Competitiveness of Agriculture in International Trade: A Global Perspective". The authors gratefully acknowledge the financial support.

\section{Corresponding authors}

Tamás Mizik

Corvinus University of Budapest, 1093 Budapest, Fövám tér 8., Hungary

Phone: +36-1-4825368, E-mail: tamas.mizik@uni-corvinus.hu

\section{References}

[1] Ahrend, R. (2006) "Russian Industrial Restructuring: Trends in Productivity, Competitiveness and Comparative Advantage", Post-Communist Economies, Vol. 18, No. 3, pp. 277-295. E-ISSN 1465-3958, ISSN 1463-1377. DOI 10.1080/14631370600881770.

[2] Amirbekova, A. and Madiyarova, D. (2015) "Assessment of the Competitiveness of Kazakhstan's Exports”, Mediterranean Journal of Social Sciences, Vol. 6, No. 6, pp. 443-447. E-ISSN 2039-2117, ISSN 2039-9340.

[3] Balassa, B. (1965) "Trade Liberalization and Revealed Comparative Advantage", Manchester School of Economic and Social Studies, Vol. 33, No. 2, pp. 99-123. E-ISSN 1467-9957. DOI 10.1111/j.1467-9957.1965.tb00050.x.

[4] Benesova, I., Maitah, M., Smutka, L., Tomsik, K. and Ishchukova, N. (2017) "Perspectives of the Russian agricultural exports in terms of comparative advantage", Agricultural Economics Czech, Vol. 63, No. 7, pp. 1-13. E-ISSN 1805-9295, ISSN 0139-570X.

[5] Besedes, T. and Prusa, T. J. (2011) "The role of extensive and intensive margins and export growth", Journal of Development Economics, Vol. 96, No. 2, pp. 371-379. ISSN 0304-3878. DOI 10.1016/j.jdeveco.2010.08.013. 
[6] Bojnec, Š. (2001) "Trade and revealed comparative advantage measures: regional and central and east European agricultural trade", Eastern European Economics, Vol. 39, No. 2, pp. 72-98. E-ISSN 1557-9298, ISSN 0012-8775.

[7] Bojnec, Š. and Fertő, I. (2008) "European Enlargement and Agro-Food Trade", Canadian Journal of Agricultural Economics, Vol. 56, No. 4, pp. 563-579. E-ISSN 1744-7976. DOI 10.1111/j.1744-7976.2008.00148.x.

[8] Borodina, O. and Krupin, V. (2018) "Is it Possible to Utilise the Agricultural Potential of Ukraine under the Current Agrarian System?”, EuroChoices, Vol. 17, No. 1, pp. 46-51. E-ISSN 1746-692X. DOI 10.1111/1746-692X.12151

[9] Buchenrieder, G., Hanf, J. H. and Pieniadz, A. (2009) "20 Years of transition in the agri-food sector", German Journal of Agricultural Economics, Vol. 58, No. 7, pp. 285-293. ISSN 21914028.

[10] Cimpoies, L. (2013) “Agri-food Trade - A Path to Agricultural Development of Moldova", Scientific Vol. 13, No. 2, pp. 49-56. E-ISSN 2285-3952, ISSN 2284-7995.

[11] Cleves, M. A., Gould, W. W. and Gutierrez, R. G. (2004) “An Introduction to Survival Analysis using Stata", Stata Press, USA, 308 p. ISBN 1881228843.

[12] Csaki, C. and Forgacs, C. (2008) "Agricultural Economics and Transition: What was expected, what we observed, the lessons learned", Proceedings of Joint IAAE-EAAE Seminar held in Budapest, September 2007. IAMO, Halle, 326 p.

[13] Deardorff, A. V. (2011) "Comparative advantage: The theory behind measurement", pp. 27-40. In: OECD: Globalisation, Comparative Advantage and the Changing Dynamics of Trade. OECD Publishing, Paris, France, 347 p. DOI 10.1787/9789264113084-3-en.

[14] FAO (2019) "Faostat". [Online]. Available: http://www.fao.org/faostat/en/\#data [Accessed: 16 May 2019).

[15] Freinkman, L., Polyakov, E. and Revenco, C. (2004) "Trade Performance and Regional Integration of the CIS Countries", In: World Bank Working Paper No. 38: 69 p. ISBN 978-0-8213-5896-2. DOI 10.1596/0-8213-5896-0.

[16] Gorton, M. and White, J. (2009) "Export strategies and performance in the CIS: case study evidence from the dairy sector", Post-Communist Economies, Vol. 21, No. 4, pp. 475-494. E-ISSN 1465-3958, ISSN 1463-1377. DOI 10.1080/14631370903339864.

[17] Héberger, K. (2010) "Sum of ranking differences compares methods or models fairly", $\operatorname{Tr} A C \operatorname{Trends}$ in Analytical Chemistry, Vol. 29, No. 1, pp.101-109. ISSN 0165-9936. DOI 10.1016/j.trac.2009.09.009.

[18] Héberger, K. and Kollár-Hunek, K. (2011) "Sum of ranking differences for method discrimination and its validation: comparison of ranks with random numbers", Journal of Chemometrics, Vol. 25, No. 4, pp. 151-158. ISSN 1099-128X. DOI 10.1002/cem.1320.

[19] Hoang, V. V. and Tran, K. T. (2019) “Comparative Advantages of Alternative Crops: A Comparison Study in Ben Tre, Mekong Delta, Vietnam”, AGRIS on-line Papers in Economics and Informatics, Vol. 11, No. 1, pp. 35-47. ISSN 1804-1930. DOI 10.7160/aol.2019.110104.

[20] Ishchukova, N. and Smutka, L. (2013) "Revealed comparative advantage of Russian agricultural exports", Acta Universitatis Agriculturae et Silviculturae Mendelianae Brunensis (Czech Republic), Vol. 61, No. 4, pp. 941-952. E-ISSN 2464-8310, ISSN 1211-8516. DOI 10.11118/actaun201361040941.

[21] Jambor, A. and Babu, S. (2016) “Competitiveness of Global Agriculture: Policy Lessons for Food Security”, Springer, 199 p. ISBN 978-3-319-44876-3. DOI 10.1007/978-3-319-44876-3.

[22] Kalinina, K. (2017) "3 years of embargo in Russia: The winners and losers", Russia Beyond, August 6 [Online]. Available: https:/www.rbth.com/business/2017/08/06/3-years-of-embargo-in-russiathe-winners-and-losers_816898 [Accessed: 16 May 2019].

[23] Karasova, N. (2016) "Comparative advantages in international trade of Ukraine's agriculture", Management Theory and Studies for Rural Business and Infrastructure Development, Vol. 38, No. 3, pp. 230-238. E-ISSN 2345-0355. DOI 10.15544/mts.2016.18. 
[24] Khatibi, A. (2008) "Kazakhstan's revealed comparative advantage vis-à-vis the EU-27”, Ecipe Working Paper No. 3., 12 p. [Online]. Available: http://ecipe.org/publications/kazakhstan2019srevealed-comparative-advantage-vis-a-vis-the-eu-27/ [Accessed: 1 April 2019].

[25] Kožar, M., Pintar, M., Volk, T., Rednak, M., Rac, I. and Erjavec, E. (2016) “Agriculture and agricultural policy in Eastern European Neighbourhood”, $155^{\text {th }}$ EAAE Seminar, Kiev, Ukraine, September 19-21, 2016.

[26] Lerman, Z., Csaki, Cs. and Feder, G. (2004) "Agriculture in transition: Land policies and evolving farm structures in post-Soviet countries", Lanham, Lexington Books. 254 p. ISBN 978-0-7391-0806-2.

[27] Liapis, P. S. (2011) "Changing patterns of trade in processed agricultural products", pp. 121-150. In: OECD: Globalisation, Comparative Advantage and the Changing Dynamics of Trade. OECD Publishing, Paris, France, 347 p. ISBN 9789264113084. DOI 10.1787/9789264113084-en.

[28] Liefert, W. (2002) "Comparative (dis?)advantage in Russian agriculture", American Journal of Agricultural Economics, Vol. 84, No. 3, pp. 762-767. E-ISSN 1467-8276, ISSN 0002-9092. DOI 10.1111/1467-8276.00334.

[29] Madiyarova, D., Amirbekova, A., and Syrlybayev, M. (2018) “Comparative advantages of Kazakhstan assessed by the Balassa Index: consistently competitive exports are limited to raw materials with low added value", Journal of Business and Retail Management Research, Vol. 12, No. 3, pp. 201-210. E-ISSN 2056-6271, ISSN 1751-8202. DOI 10.24052/JBRMR/V12IS03/ART-18.

[30] Maslova, V., Zaruk, N., Fuchs, C., and Avdeev, M. (2019) "Competitiveness of Agricultural Products in the Eurasian Economic Union”, Agriculture, Vol. 9, No. 3, 14 p. ISSN 2077-0472. DOI 10.3390/agriculture9030061

[31] Maryam, J., Banday, U. and Mittal, A. (2018) "Trade intensity and revealed comparative advantage: an analysis of Intra-BRICS trade", International Journal of Emerging Markets, Vol. 13, No. 5, pp. 1182-1195. ISSN 1746-8809. DOI 10.1108/IJoEM-09-2017-0365.

[32] Mogilevskii, R. and Akramov, K. (2014) "Trade in Agricultural and Food Products in Central Asia", University of Central Asia, Working paper No. 27, 28 p. DOI 10.2139/ssrn.2946713.

[33] RPA (2009) "Doctrine of Food Security, Strategy of National Security of the Russian Federation till 2020 (In Russian) (enacted by the RF President Decree No. 537 of May 12, 2009)", Russian Presidential Administration. [Online]. Available: http://kremlin.ru/acts/6752 [Accessed: 23 April 2019].

[34] Vigneau, E. and Qannari, E. M. (2003) "Clustering of variables around latent components", Communication in Statistics- Simulations and Computation, Vol. 32, No. 4, pp. 1131-1150. E-ISSN 1532-4141, ISSN 0361-0918. DOI 10.1081/SAC-120023882.

[35] Wijnands, J. H. M., van Berkum, S. and Verhoog, D. (2015) "Competitiveness of CIS and EU agrifood chains, Quantifying Porter's diamond", LEI Wageningen University, 74. p. DOI 10.13140/RG.2.1.3657.7360.

[36] World Bank WDI (2019) "World Development Indicators" [Online]. Available: http://databank. worldbank.org/data/reports.aspx?source=world-development-indicators [Accessed: 16 May 2019].

[37] World Bank WITS (2019) "World Integrated Trade Solution database". [Online]. Available: http://wits.worldbank.org/ [Accessed: 10 May 2019].

[38] WTO (2019) “Time series database". [Online]. Available: http://stat.wto.org/StatisticalProgram/ WSDBStatProgramHome.aspx?Language=E [Accessed: 10 May 2019].

[39] Zhemoyda, O. and Gerasymenko, N. (2009) "Concentration of agriculture and competitive advantages of East-European countries", Conference proceeding of the $113^{\text {th }}$ EAAE Seminar "A resilient European food industry and food chain in a challenging world", Chania, Crete, Greece, September 3-6. 


\section{Appendix}

\begin{tabular}{|l|c|}
\hline Product groups by HS2 classification & Code \\
\hline Live animals & 1 \\
\hline Meat and edible meat offal & 2 \\
\hline Fish and crustaceans, molluscs and other aquatic invertebrates & 3 \\
\hline Dairy produce, birds' eggs, natural honey, edible products of animal origin not elsewhere specified or included & 4 \\
\hline Products of animal origin, not elsewhere specified or included & 5 \\
\hline Live trees and other plants, bulbs, roots and the like, cut flowers and ornamental foliage & 6 \\
\hline Edible vegetables and certain roots and tubers & 7 \\
\hline Edible fruit and nuts, peel of citrus or melons & 8 \\
\hline Coffee, tea, mat and spices & 9 \\
\hline Cereals & 10 \\
\hline Products of the milling industry, malt, starches, inulin, wheat gluten & 11 \\
\hline Oil seeds and oleaginous fruits, miscellaneous grains, seeds and fruit, industrial or medicinal plants, straw and fodder & 12 \\
\hline Lac, gums, resins and other vegetable saps and extracts & 13 \\
\hline Vegetable plaiting materials, vegetable products not elsewhere specified or included & 14 \\
\hline Animal or vegetable fats and oils and their cleavage products, prepared edible fats, animal or vegetable waxes & 15 \\
\hline Preparations of meat, of fish or of crustaceans, molluscs or other aquatic invertebrates & 16 \\
\hline Sugar and sugar confectionery & 17 \\
\hline Cocoa and cocoa preparations & 18 \\
\hline Preparations of cereals, flour, starch or milk, pastrycooks' products & 19 \\
\hline Preparations of vegetables, fruit, nuts or other parts of plants & 20 \\
\hline Miscellaneous edible preparations & 21 \\
\hline Beverages, spirits and vinegar & 22 \\
\hline Residues and waste from food industries, prepared animal fodder & 23 \\
\hline Tobacco and manufactured tobacco substitutes & 24 \\
\hline
\end{tabular}

Source: World Bank WITS database (2019)

Annex 1: HS2 classification of the agricultural product groups. 